\title{
Bufalin increases sensitivity to AKT/mTOR-induced autophagic cell death in SK-HEP-1 human hepatocellular carcinoma cells
}

\author{
SHIH-CHANG TSAI ${ }^{1 *}$, JAI-SING YANG ${ }^{2 *}$, SHU-FEN PENG $^{1,4}$, CHI-CHENG LU $^{5}$, JO-HUA CHIANG ${ }^{5}$, \\ JING-GUNG CHUNG ${ }^{1}$, MENG-WEI LIN ${ }^{1}$, JEN-KUN LIN ${ }^{1,6}$, SAKAE AMAGAYA ${ }^{3,7}$, CINDERELLA \\ WAI-SHAN CHUNG ${ }^{2}$, THENG-THANG TUNG ${ }^{2}$, WEN-WEN HUANG ${ }^{1}$ and MICHAEL T. TSENG ${ }^{8}$
}

\begin{abstract}
Departments of ${ }^{1}$ Biological Science and Technology and ${ }^{2}$ Pharmacology, ${ }^{3}$ Tsuzuki Institute for Traditional Medicine, China Medical University, Taichung 404; ${ }^{4}$ Department of Medical Research, China Medical University Hospital, Taichung 404; ${ }^{5}$ Department of Life Sciences, National Chung Hsing University, Taichung 402; ${ }^{6}$ Institute of Biochemistry and Molecular Biology, College of Medicine, National Taiwan University, Taipei 10617, Taiwan, R.O.C.;

${ }^{7}$ Department of Kampo Pharmaceutical Sciences, Nihon Pharmaceutical University, Saitama 362-0806, Japan;

${ }^{8}$ Department of Anatomical Sciences and Neurobiology, School of Medicine, University of Louisville, KY 40202, USA
\end{abstract}

Received May 11, 2012; Accepted July 10, 2012

DOI: $10.3892 /$ ijo.2012.1579

\begin{abstract}
Bufalin is the major component of Chan-Su (a traditional Chinese medicine, TCM) extracts from the venom of Bufo bufo gargarizan. In the present study, we investigated the pharmacological mechanisms of cell cycle arrest and autophagic cell death induced by bufalin in SK-HEP-1 human hepatocellular carcinoma cells in vitro. Bufalin inhibited cell survival by MTT assay and increased cell death by trypan blue exclusion assay in a concentration-dependent manner. In addition, bufalin induced $\mathrm{G}_{2} / \mathrm{M}$ phase arrest by reducing $\mathrm{CDK} 1$ activity. Bufalin triggered DNA fragmentation and apoptotic cell death in SK-HEP-1 cells by DNA gel electrophoresis, TUNEL and caspase-3 activity assay, while bufalin induced autophagic cell death by double-membrane vacuoles (transmission electron microscopy, TEM), acidic vesicular organelles (acridine orange staining) and cleavage of microtubule-associated protein 1 light chain 3 (LC3). Protein expression levels of cyclin A and B, CDK1, phospho-CDK1 (Thr161), Cdc25c, phospho-Cdc25c (Ser198), phospho-AKT (Thr308), phospho-AKT (Ser473), phospho-mTOR (Ser2481) were downregulated. In contrast,
\end{abstract}

Correspondence to: Professor Wen-Wen Huang, Department of Biological Science and Technology, China Medical University, no. 91, Hsueh-Shih Road, Taichung 40402, Taiwan, R.O.C.

E-mail:wwhuang@mail.cmu.edu.tw

Dr Michael T. Tseng, Department of Anatomical Sciences and Neurobiology, School of Medicine, University of Louisville, no. 500, South Preston Street, Louisville, KY 40202, USA

E-mail: mttsen01@exchange.louisville.edu

*Contributed equally

Key words: bufalin, traditional chinese medicine, autophagic cell death, AKT/mTOR, SK-HEP-1 cells protein expression levels of the Chk1, Weel, LC3-II, Beclin-1, Atg 5, Atg 7 and Atg 12 were upregulated in SK-HEP-1 cells after bufalin treatment. Inhibition of autophagy by 3-methyladenine (an inhibitor of class III phosphatidylinositol-3 kinase; 3-MA) or bafilomycin A1 (an inhibitor of the vacuolar proton pump of lysosomes and endosomes) reduced the effect of bufalin on cell viability and enhanced the effect of bufalin on apoptosis. In conclusion, bufalin triggered autophagic cell death and $\mathrm{G}_{2} / \mathrm{M}$ phase arrest through the AKT/mTOR signaling pathway in SK-HEP-1 cells. Our findings showed that bufalin may be potentially efficacious in the treatment of human hepatocellular carcinoma.

\section{Introduction}

In Taiwan, 33.5 per 100,000 people die from liver cancer each year according to the Department of Health, Executive Yuan in 2010s (http://www.doh.gov.tw/EN2006/index EN.aspx/). Hepatocellular carcinoma (HCC) is one of the most common primary cancers of the liver in the world and in Taiwan, and accounts for more than $90 \%$ of all primary liver tumors (1). HCC is the sixth most common cancer and the third most common cause of death from cancer worldwide (2,3). HCC is a high degree of malignancy but poor prognosis disease, and most patients with HCC are not curable (4). Chemotherapy is one of the treatment options in HCC, but these outcomes are not fully satisfactory (5). Multidrug resistance gene is overexpressed in HCC, which results in un-sensitizing chemotherapeutic agents (6-8). Therefore, discovery to more effective chemotherapeutic agents for HCC is urgently needed.

The most effective strategy for curing $\mathrm{HCC}$ is to induce cell cycle arrest and cell death $(9,10)$. The promotion of cell cycle progression at $\mathrm{G}_{2} / \mathrm{M}$ phase has been intensively investigated. Cyclin-dependent protein kinase 1 (CDK1)/cyclin B complex plays a major role in the regulation of the cell cycle in $\mathrm{G}_{2} / \mathrm{M}$ phase. When the cells progress from $S$ phase into $G_{2} / M$ phase, the CDK1/cyclin B1 complex becomes active, suggesting 
that CDK1 has undergone an activating phosphorylation (on Thr161), and the inhibitory phosphorylation (on Thr14 and Tyr15) removed by active Cdc $25 \mathrm{c}$ phosphatase $(11,12)$. The Weel kinase is regulating $\mathrm{G}_{2} / \mathrm{M}$ phase transition by phosphorylation of CDK1 at Tyr15. In addition, Chk1 is the essential kinase in the $\mathrm{G}_{2} / \mathrm{M}$ checkpoint by phosphorylating $\mathrm{Cdc} 25 \mathrm{c}$ in response to cellular damaging and antimitotic agents (13-15).

Three major morphologically processes lead to cell death, apoptosis, necrosis and autophagic cell death $(16,17)$. Autophagic cell death, or cellular self-digestion, occurs in multi-cellular organisms and plays an important role in normal physiology in animals (18). When the cells undergo nutrient starvation, cellular damage, pathogen infection, aging and degenerative processes, autophagic cell death is required for the promotion of cellular survival (19,20). Autophagy (self-eating), causes specific morphological and biochemical modification, and is considered as programmed cell death type II (apoptosis, programmed cell death type I), which occurs in some situations and then induces cell death $(21,22)$. The cytoplasm and double smooth membrane (a phagophore) of various organelles such as mitochondria, endoplasmic reticulum (ER) and peroxisomes are sequestered by a membrane to form an autophagosomes and then the autophagosome fuses with the lysosome, forming autophagolysosome, finally resulting in degradation of the captured proteins/organelles by lysosomal enzymes (18,23-25). Many studies have demonstrated that a group of autophagyrelated proteins (Atg) is involved in autophagic cell death. The membrane nucleation is mediated by a class III phosphatidylinositol 3-kinase and Beclin 1. The production of autophagosome is necessary for the recruitment of Atg12-Atg7-Atg5 complex and microtubule-associated protein 1 light chain 3 (LC3) (26-29). There are two major forms of LC3, type I is cytosolic and type II is membrane-bound. When cells undergo autophagic cell death, LC3-II, an autophagosomal marker, increases from the conversion of LC3-I (30). Promotion of autophagic cell death from cancer cells is one of the best strategies in chemotherapy (31-33).

Bufalin, a digoxin-like chemical reagent, is one of the major Chinese tradition medicine Chan-Su components extracted from dried toad venom from the skin glands of Bufo bufo gargarizan or Bufo melanostictus. It has been demonstrated that bufalin exhibits significant anticancer activities against many human tumor cells in vitro and in vivo. The anticancer activities by bufalin are involved in the induction of cell differentiation, cell cycle arrest, apoptosis and inhibition of cell metastasis. Xie et al demonstrated that bufalin induces autophagic cell death through reactive oxygen species (ROS) generation and JNK activation in HT29 human colon cancer cells (34). The anticancer activities of bufalin have been reported, however, no comprehensive studies have been reported on the effects of bufalin on human hepatocellular carcinoma cells. The goal of this study is to explore whether the antitumor activity of bufalin mediates through the direct cytotoxic effect and to understand the molecular mechanisms in human hepatocellular carcinoma SK-HEP-1 cells. The present study is focused on the cell cycle arrest and autophagy-induced by bufalin in the SK-HEP-1 cells. Our results demonstrate that bufalin inhibits cells viability, induces autophagic cell death, and simultaneously causes cell cycle arrest in $\mathrm{G}_{2} / \mathrm{M}$ phase through the AKT/mTOR signaling pathway in SK-HEP-1 cells.

\section{Materials and methods}

Chemicals and reagents. Acridine orange (AO), agarose, bafilomycin, bufalin, dimethyl sulfoxide (DMSO), 3-methyladenine (3-MA), propidium iodide (PI), RNase A, 3-(4,5-dimethylthiazol-2-yl)-2,5-diphenyl-2H-tetrazolium bromide (MTT), proteinase K, and Triton X-100 were obtained from Sigma Chemical Co. (St. Louis, MO, USA). Fetal bovine serum (FBS), L-glutamine, LC3B antibody kit for autophagy, penicillin/streptomycin, RPMI-1640 medium, trypan blue solution and Trypsin-EDTA were purchased from Invitrogen/Life Technologies (Carlsbad, CA, USA). AKT kinase assay Kit was purchased from Cell Signaling Technology (Danvers, MA, USA). Caspase-3 activity assay kit was purchased from R\&D Systems Inc. (Minneapolis, MN, USA). CDK1 kinase activity kit was purchased from Medical \& Biological Laboratories International (Nagoya, Japan). Tdt-mediated deoxyuridine triphosphate nick end labeling (TUNEL) assay kit was purchased from Roche Diagnostics (GmBH, Mannheim, Germany). Primary antibodies (anti-cyclin A, anti-cyclin B, anti-CDK1, anti-Cdc25c, anti-Chk1, anti-Weel, anti-PARP, anti-mTOR and anti-GAPDH), and second antibodies for western blot analysis were obtained from Santa Cruz Biotechnology Inc. (Santa Cruz, CA, USA). The primary antibodies [anti-phospho-CDK1 (Thr161), phospho-Cdc25c (Ser198), anti-phospho-AKT (Thr308), anti-phospho-AKT (Ser473), anti-phospho-mTOR (Ser2481) and anti-caspase-3, anti-LC3-II, anti-Beclin-1, antiAtg 5, anti-Atg 7 and anti-Atg 12] were obtained from Cell Signaling Technology. Antibody against $\beta$-actin was purchased from Sigma Chemical Co. All peroxidase-conjugated secondary antibodies were purchased from Santa Cruz Biotechnology Inc. The enhanced chemiluminescence (ECL) detection kit was purchased from Pierce Chemical (Rockford, IL, USA).

Cell culture. The human hepatocellular carcinoma cell line (SK-HEP-1) was obtained from the Food Industry Research and Development Institute (Hsinchu, Taiwan). Cells were cultured in $75-\mathrm{cm}^{2}$ tissue culture flasks at $37^{\circ} \mathrm{C}$ under a humidified $5 \% \mathrm{CO}_{2}$ atmosphere in RPMI-1640 medium containing $10 \% \mathrm{FBS}, 2 \mathrm{mM}$ of L-glutamine, $100 \mathrm{U} / \mathrm{ml}$ of penicillin and $100 \mu \mathrm{g} / \mathrm{ml}$ of streptomycin.

Cell viability and morphology. Cell viability was evaluated using the MTT assay (35). SK-HEP- 1 cells ( $1 \times 10^{4}$ cells) in 96-well plates were incubated with 0, 25, 50, 100 and $200 \mathrm{nM}$ of bufalin or $0.1 \%$ DMSO as a vehicle control for $24 \mathrm{~h}$. For incubation with the inhibitors, cells were pretreated with 3-MA (10 mM) or bafilomycin $(10 \mathrm{nM})$ for $1 \mathrm{~h}$, followed by treatment with or without bufalin $(100 \mathrm{nM})$. After washing the cells, RPMI-1640 medium containing MTT $(0.5 \mathrm{mg} / \mathrm{ml})$ of was added to each well. The cells were incubated for $4 \mathrm{~h}$ at $37^{\circ} \mathrm{C}$ the supernatant was removed. The formed formazan crystals in viable cells were dissolved with isopropanol in $0.04 \mathrm{~N} \mathrm{HCl}$. The absorbance of each well was measured at $570 \mathrm{~nm}$ with ELISA reader with a reference wavelength of $620 \mathrm{~nm}$. All experiments were performed in triplicate and the cell viability was expressed as percentage of the control as previously described. Cell morphological examination of autophagic vacuoles was determined utilizing a phase-contrast microscope. 
Assessment for cell death. Cell death was evaluated using a trypan blue assay $(36,37)$. SK-HEP-1 cells $\left(2.5 \times 10^{5}\right.$ cells $)$ in 24-well plates were incubated with 0, 25, 50, 100 and $200 \mathrm{nM}$ of bufalin for $24 \mathrm{~h}$. At the end of incubation, cells were stained in the $0.25 \%$ trypan blue solution and then determined cell number by Countess Automated Cell Counter (Invitrogen/Life Technologies) as previously described.

Cell cycle progression. The $2.5 \times 10^{5}$ cells of SK-HEP-1 cells in 24-well plate were exposed to bufalin (50 and $100 \mathrm{nM}$ ) for $24 \mathrm{~h}$. At the end of incubation, cells were then collected, fixed in $70 \%$ ethanol overnight, then washed in PBS once, and re-suspended in $500 \mu \mathrm{l}$ of $\mathrm{Na}_{2} \mathrm{HPO}_{4}(192 \mathrm{mM})$, citric acid $(4 \mathrm{mM}) \mathrm{pH} 7.8$ at $25^{\circ} \mathrm{C}$ for $30 \mathrm{~min}$. The cells were stained with $0.5 \mathrm{ml}$ of PBS containing RNase $(1 \mathrm{mg} / \mathrm{ml})$, PI $(10 \mu \mathrm{g} / \mathrm{ml})$ for $30 \mathrm{~min}$ in the dark, and then analyzed by flow cytometry as previously described $(38,39)$.

CDK1 kinase activity. CDK 1 kinase activity was performed according to the manufacturer's protocols (CycLex ${ }^{\circledR} \mathrm{Cdc} 2-\mathrm{Cyclin}$ B Kinase Assay Kit; MBL International Corporation, Japan) (40). SK-HEP-1 cells were seeded into 75-T flasks (1x107/each). Bufalin (100 nM) were added and incubated for 0, 6, 12 and $24 \mathrm{~h}$. At the end of incubation, cells were harvested, washed twice with ice-cold PBS, and then re-suspended the cell pellet with $500 \mu \mathrm{l}$ of extraction buffer (20 mM Tris-HCl, pH 8.5, $150 \mathrm{mM} \mathrm{NaCl}, 0.2 \%$ NP-40, $1 \mathrm{mM}$ DTT, $1 \mathrm{mM}$ EDTA, $1 \mathrm{mM}$ EGTA, $0.2 \mathrm{mM}$ PMSF, $1 \mu \mathrm{g} / \mathrm{ml}$ pepstatin, $0.5 \mu \mathrm{g} / \mathrm{ml}$ leupeptin, $5 \mathrm{mM} \beta$-glycerophosphate, $5 \mathrm{mM} \mathrm{NaF}, 1 \mathrm{mM} \mathrm{Na} \mathrm{VO}_{4}, 5 \mathrm{mM}$ $\beta$-mercaptoethanol). Cell extracts were diluted in a 1:5 ratio with Q-buffer (20 mM Tris-HCl, pH 8.5,0.2 mM EDTA, $1 \mathrm{mM}$ EGTA, $1 \mu \mathrm{g} / \mathrm{ml}$ pepstatin, $0.5 \mu \mathrm{g} / \mathrm{ml}$ leupeptin, $0.2 \mathrm{mM} \mathrm{Na}_{3} \mathrm{VO}_{4}$, $5 \mathrm{mM} \beta$-mercaptoethanol). The CDK1 activity was measured absorbance using ELISA reader at OD450. All results were performed in three independent experiments.

DNA gel electrophoresis. SK-HEP-1 cells were seeded into

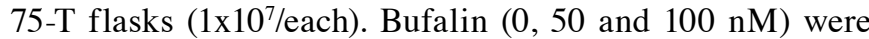
added and incubated for $24 \mathrm{~h}$. At the end of incubation, cells were harvested and washed twice with ice-cold PBS. The cell pellets were re-suspended in lysis buffer $(20 \mathrm{mM}$ Tris- $\mathrm{HCl}$, pH 8.0, 10 mM EDTA, 0.2\% Triton X-100). Cell lysates were treated with $0.1 \mathrm{mg} / \mathrm{ml}$ proteinase $\mathrm{K}$ at $50^{\circ} \mathrm{C}$ for $12 \mathrm{~h}$, followed by $50 \mu \mathrm{g} / \mathrm{ml}$ RNase A at $37^{\circ} \mathrm{C}$ for $30 \mathrm{~min}$. After precipitation, the DNA was subjected to electrophoresis in a $1.5 \%$ agarose gel (Sigma-Aldrich Corp.). DNA fragmentation on agarose gel was stained with $1 \mu \mathrm{g} / \mathrm{ml}$ ethidium bromide (EtBr, Invitrogen/Life Technologies) in 0.5X TBE buffer and examined in photographs taken under UV light as previously described $(13,41)$.

TUNEL staining. TUNEL staining was performed according to the manufacturer's protocol (in situ cell death detection kit; Roche Diagnostics) $(13,41)$. The $2.5 \times 10^{5}$ cells of SK-HEP-1 cells seeded in each well of 24-well plates were exposed to bufalin $(25,50$ and $100 \mathrm{nM})$ or paclitaxel $(100 \mathrm{nM})$ for $24 \mathrm{~h}$. At the end of incubation, cells were collected then fixed in $70 \%$ ethanol then washed twice with ice-cold PBS, and incubated in the dark for $30 \mathrm{~min}$ at $37^{\circ} \mathrm{C}$ in $100 \mu \mathrm{l}$ of TdT-containing solution. Following TUNEL staining, all samples were washed once. TUNEL positive cells were analyzed by flow cytometry using a FACSCalibur (Becton Dickinson). The median fluorescence intensity was quantities by CellQuest software. TUNEL assays were performed in triplicate on three independent experiments.

Caspase-3 activity assay. SK-HEP-1 cells $\left(1 \times 10^{7}\right.$ cells/75-T flask) were treated with bufalin $(25,50$ and $100 \mathrm{nM})$ or paclitaxel $(100 \mathrm{nM})$ for $24 \mathrm{~h}$. At the end of incubation, cells were harvested and re-suspended in a lysis buffer [50 mM Tris- $\mathrm{HCl}(\mathrm{pH} 7.4)$, $1 \mathrm{mM}$ EDTA, $10 \mathrm{mM}$ EGTA, $10 \mathrm{mM}$ digitonin and $2 \mathrm{mM}$ DTT]. Cell lysates (50 $\mu$ g protein) were incubated with caspase-3 specific substrates (Ac-DEVD-pNA) (R\&D Systems Inc.) for $1 \mathrm{~h}$ at $37^{\circ} \mathrm{C}$. The caspase- 3 activity was determined by measuring $\mathrm{OD}_{405}$ of the released pNA $(42,43)$.

Transmission electron microscopy. SK-HEP-1 cells (1x10 ${ }^{6}$ cells/6-well) were treated with bufalin $(100 \mathrm{nM})$ for $24 \mathrm{~h}$. At the end of incubation, cells washing three times with PBS, cells were fixed for $30 \mathrm{~min}$ at room temperature in $2 \%$ paraformaldehyde and $2.5 \%$ glutaraldehyde in PBS buffer. The cells were rinsed twice in the same buffer and subsequently post fixed in $1 \%$ osmium tetraoxide. After rinsing followed by dehydration in graded alcohol series, the cells were embedded in LR white resin and polymerized at $70^{\circ} \mathrm{C}$ overnight. Ultrathin sections were then cut with a diamond knife and loaded onto TEM grids. The sections were examined by a Philips CM10 electron microscope at accelerating voltage of $120 \mathrm{kV}$ and micrographs were taken (44).

Detection of acidic vesicular organelles (AVO) with acridine orange $(A O)$. SK-HEP-1 cells $\left(1 \times 10^{6}\right.$ cells/6-well $)$ were treated with bufalin $(100 \mathrm{nM})$ for $24 \mathrm{~h}$. At the end of incubation, cells were harvested. To detect and quantify acidic vesicular organelles (AVO), cells were stained with acridine orange (AO). The number of acridine orange positive cells was analyzed by flow cytometry using a FACSCalibur (Becton Dickinson). Cell morphology was examined using phase-contrast and fluorescence microscopy (Nikon, Melville, NY, USA). All results were performed in three independent experiments (45).

Immunofluorescence analysis. LC-3 staining was performed according to the manufacturer's protocol (LC3 antibody kit for autophagy; Invitrogen/Life Technologies) $(46,47)$. SK-HEP-1 cells $\left(1 \times 10^{6}\right.$ cells/6-well) in 6-well flask were treated with bufalin $(100 \mathrm{nM})$ for $24 \mathrm{~h}$. At the end of incubation, cells were harvested then fixed with $3.7 \%$ formaldehyde in PBS for $15 \mathrm{~min}$. Cells were washed three times with PBS, added 0.2\% Triton X-100 in PBS to the cells, and incubated for $15 \mathrm{~min}$ at room temperature. Permeabilized cells were incubated with an anti-LC3 antibody (1:150) at $4^{\circ} \mathrm{C}$ overnight, and followed by incubation with an Alexa Fluor 488-conjugated secondary antibody (1:200; Invitrogen) for $1 \mathrm{~h}$. The images were taken under a fluorescence microscopy (Nikon). The number of LC-3 positive cells was analyzed by flow cytometry using a FACSCalibur (Becton Dickinson). All results were performed in three independent experiments (48).

Western blot analysis. SK-HEP-1 cells $\left(1 \times 10^{7}\right.$ cells/75-T flask) were treated with bufalin (100 nM) for $0,2,4,6,8,12,18$ and $24 \mathrm{~h}$. At the end of incubation, cytosolic or total proteins were prepared and determined as previously described. Protein lysates were sonicated and the supernatants were boiled in SDS sample buffer 
A

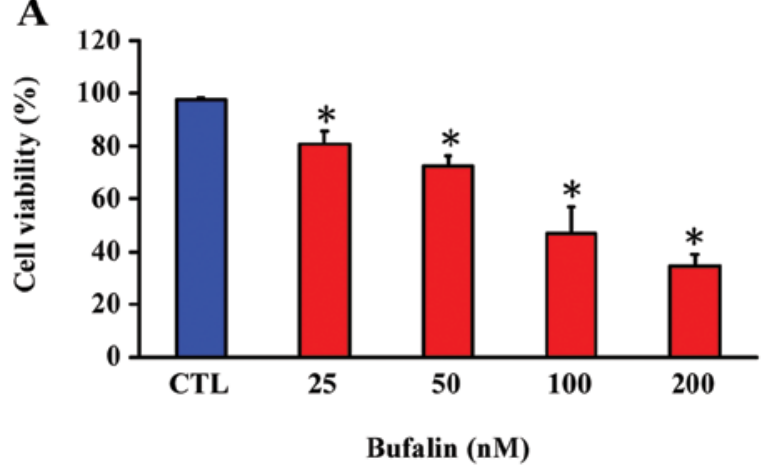

C

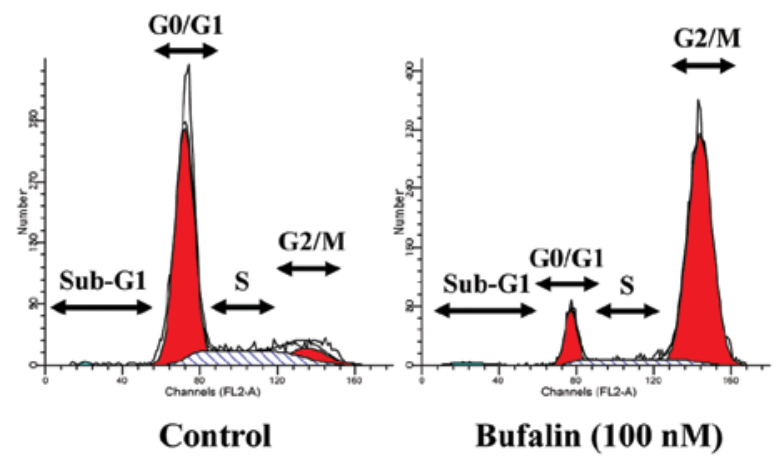

B
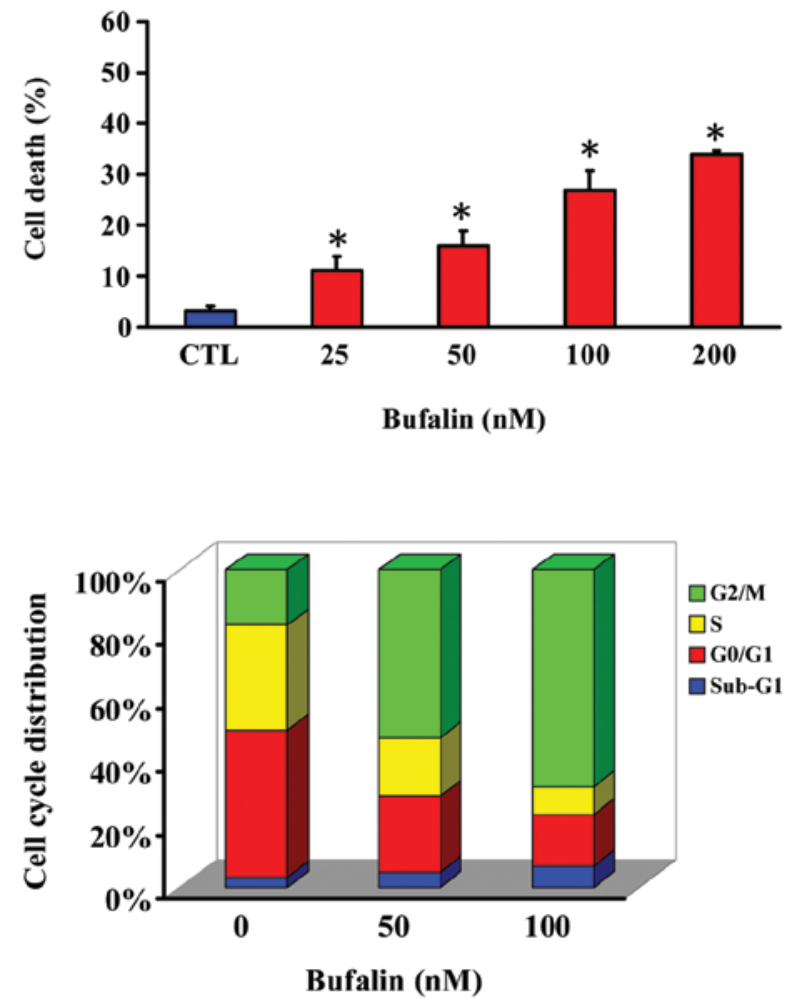

Figure 1 . The effects of bufalin on cell viability and cell cycle distribution in SK-HEP-1 cells. (A) Cells were treated with bufalin ( $0,25,50,100$ and $200 \mathrm{nM})$ for $24 \mathrm{~h}$. Percentage of viable cells was determined by the MTT method. (B) Cells were treated with bufalin (0, 25, 50, 100 and $200 \mathrm{nM})$ for $24 \mathrm{~h}$. Percentage of cell death was determined by the trypan blue exclusion assay. (C) Cells were treated with 50 or $100 \mathrm{nM}$ of bufalin for $24 \mathrm{~h}$. The cell cycle distribution was determined using flow cytometric analysis and cell cycle distribution was quantified. Data are presented as the mean \pm SEM of three independent experiments. ${ }^{*}<0.05$, significantly different compared with control treatment.

for $5 \mathrm{~min}$. The protein concentration was measured by using a BCA assay kit (Pierce Chemical). Equal amounts of cell lysates were run on 10 to $12 \%$ SDS-polyacrylamide gel electrophoresis and electro-transferred to a nitrocellulose membrane by using the iBot Dry Blotting System (Invitrogen/Life Technologies). The transferred membranes were blocked for $1 \mathrm{~h}$ in $5 \%$ nonfat dry milk in Tris buffered saline/Tween-20 and incubated with primary antibodies at $4^{\circ} \mathrm{C}$ overnight. Membranes were washed three times with Tris-buffered saline/Tween-20 for $10 \mathrm{~min}$ and incubated with secondary HRP-conjugated antibody. The blots were developed by using an ECL kit and Kodak Bio-MAX MR film (Eastman Kodak, Rochester, NY, USA) (35).

In vitro AKT kinase assay. In vitro AKT kinase assay was performed following the protocol of the manufacturer's (Cell Signaling Technology) (46,49). In brief, SK-HEP-1 cells $\left(1 \times 10^{7}\right.$ cells/75-T flask) were treated with bufalin (100 nM) for 0, 2, 4, 6 and $8 \mathrm{~h}$. At the end of incubation, cells were lysed in ice-cold lysis buffer provided by the kit. The $200 \mu \mathrm{g}$ of protein from each time point treatment was immuno-precipitated with $2 \mu \mathrm{g}$ of anti-AKT antibody overnight. Immuno-precipitates were extensively washed, and then incubated with $1 \mu \mathrm{g}$ of glycogen synthase kinase-3 $\alpha / \beta$ (GSK-3 $\alpha / \beta$ ) fusion protein substrate in $50 \mu \mathrm{l}$ of kinase buffer for $30 \mathrm{~min}$ at $30^{\circ} \mathrm{C}$. Reactions were stopped by SDS loading buffer and samples were separated on $12 \%$ SDS-PAGE. The phospho-GSK-3 $\alpha / \beta$ (Ser219) was detected by immunoblotting.
Statistical analysis. All the statistical results were expressed as the mean \pm SEM of triplicate samples. Statistical analyses of data were done using one-way ANOVA followed by Student's t-test and ${ }^{*} \mathrm{P}<0.05$ were considered significant.

\section{Results}

Bufalin inhibits cell proliferation, promotes $G_{2} / M$ phase arrest in SK-HEP-1 cells. SK-HEP-1 cells were treated with bufalin (0, $25,50,100$ and $200 \mathrm{nM}$ ) for $24 \mathrm{~h}$. Bufalin reduced cell viability of SK-HEP-1 cells in a concentration-dependent manner as measured by the MTT assay (Fig. 1A). The half maximal (50\%) inhibitory concentration $\left(\mathrm{IC}_{50}\right)$ for a 24 -h treatment of bufalin in SK-HEP-1 cell was $110.33 \pm 5.32 \mathrm{nM}$. Fig. 1B shows that bufalin increased cell death in a concentration-dependent manner by the trypan blue exclusion assay. We then examined cell cycle distribution in SK-HEP-1 cells exposed to $100 \mathrm{nM}$ of bufalin for 24 h. These results showed $\mathrm{G}_{2} / \mathrm{M}$ accumulation after SK-HEP-1 cells were treated with $100 \mathrm{nM}$ of bufalin (Fig. 1C). Interestingly, SK-HEP-1 cells exposed to 50 and $100 \mathrm{nM}$ of bufalin have undergone cell death, but did not detect significant sub- $G_{1}$ DNA content, a typical apoptosis. Our results suggested that bufalin effectively caused $\mathrm{G}_{2} / \mathrm{M}$ arrest and then induced cell death.

Effects of bufalin on $G_{2} / M$ phase-associated protein levels in $S K-H E P-1$ cells. We investigated the $\mathrm{G}_{2} / \mathrm{M}$ phase specific protein expression levels by western blot analysis. As shown 
$\mathbf{A}$

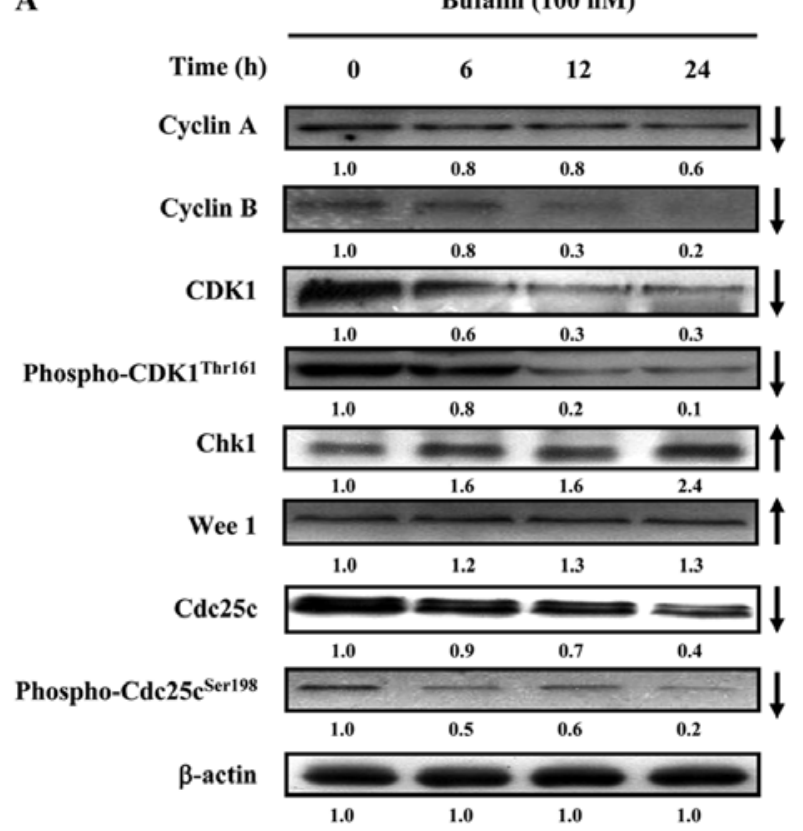

$\mathbf{A}$

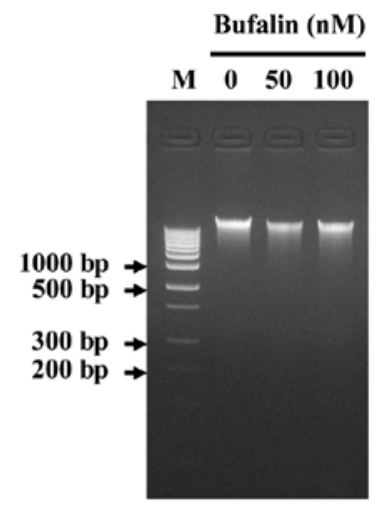

C

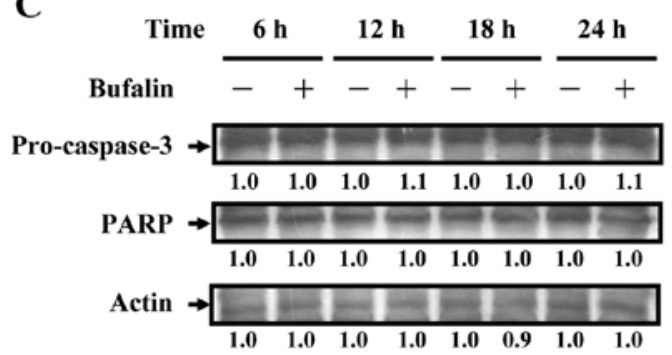

B

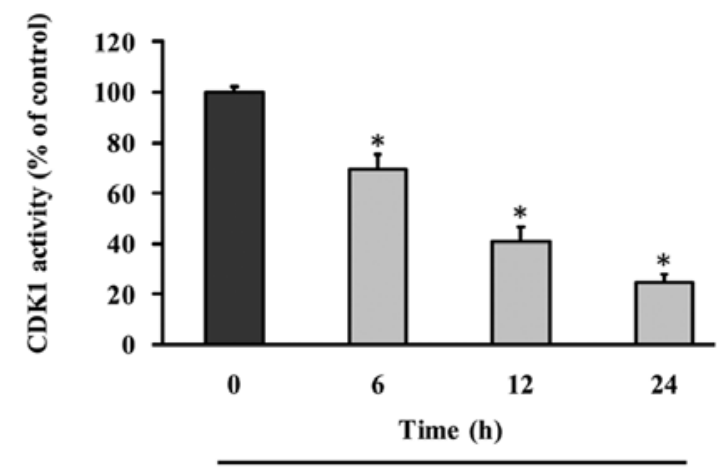

Bufalin (100 nM)

Figure 2. $G_{2} / M$ phase-associated protein levels and $C D K 1$ activity in bufalin treated SK-HEP-1 cells. (A) Cells were exposed to bufalin (100 nM) and then incubated for 0, 6, 12 and $24 \mathrm{~h}$. The protein levels of Cyclin A, Cyclin B,CDK1, phospho-CDK1 (Thr161), Chk1, Wee1, Cdc25c, phospho-Cdc25c (Ser198) and $\beta$-actin in bufalin-treated SK-HEP-1cells were determined by western blot analysis. (B) CDK1 activity was examined by an in vitro kinase activity assay. Data are presented as the mean \pm SEM of three independent experiments. ${ }^{*} \mathrm{P}<0.05$, significantly different compared with control treatment.

\section{B}
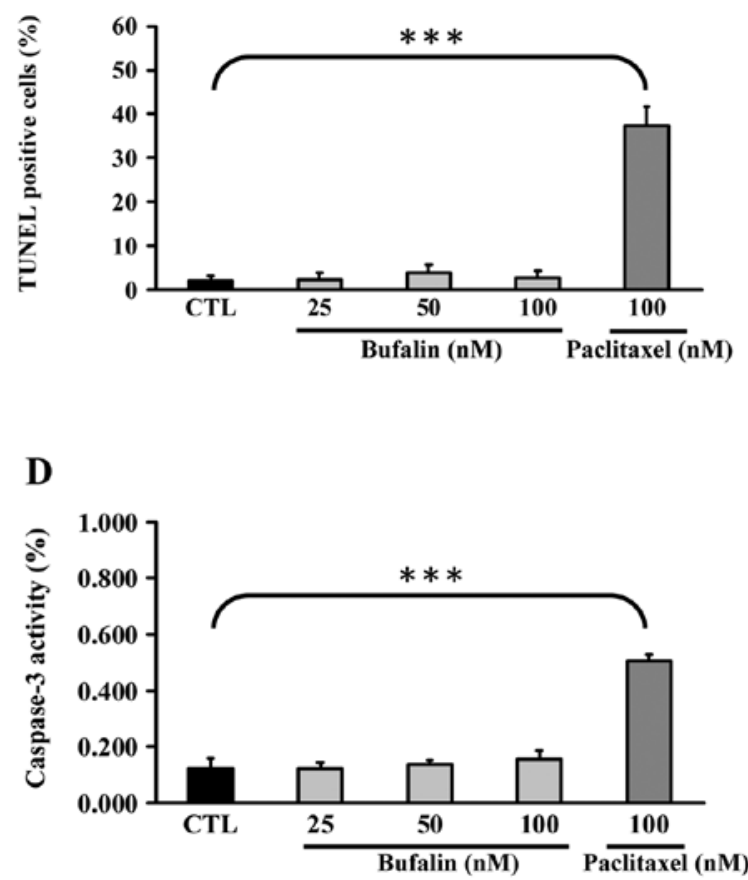

Figure 3. Effects of bufalin on apoptosis in SK-HEP-1 cells. (A) Agarose gel detection of DNA fragmentation. SK-HEP-1 cells were treated with bufalin (0,50 and $100 \mathrm{nM}$ ) for 24 h. Lanes: 1, 100 bp DNA marker; 2, vehicle; 3, cells treated with $50 \mathrm{nM}$ of bufalin; 4, cells treated with $100 \mathrm{nM}$ of bufalin. (B) TUNEL analysis was determined by flow cytometry. SK-HEP-1 cells were treated with bufalin $(0,25,50$ and $100 \mathrm{nM})$ or paclitaxel (100 nM) for $24 \mathrm{~h}$. Apoptotic cell population (TUNEL positive cells) was quantified as described in Materials and methods. (C) The protein expression levels of cleaved caspase-3 or cleaved PARP in bufalin-treated SK-HEP-1 cells. Cells were treated with $100 \mathrm{nM}$ of bufalin for the indicated time course exposure. The protein levels of cleaved caspase-3, cleaved PARP and $\beta$-actin were determined by western blot analysis. (D) The caspase- 3 activity in bufalin-treated SK-HEP-1 cells. Cells were pretreated with the specific inhibitor of caspases-3 (z-DEVD-fmk) for $1 \mathrm{~h}$ after exposure to different doses of bufalin as indicated. Data are presented as the mean \pm SEM of three independent experiments. ${ }^{*} \mathrm{P}<0.05$, significantly different compared with control treatment.

in Fig. 2A, bufalin $(100 \mathrm{nM})$ caused an increase in the protein level of Chk1 and Weel, and a decrease in the protein levels of Cyclin A, Cyclin B, CDK1, phospho-CDK1 (Thr161), Cdc25c,
phospho-Cdc25c (Ser198) for 6, 12 and $24 \mathrm{~h}$ treatment in SK-HEP-1 cells. We examined the CDK1 activity in bufalintreated SK-HEP-1 cells. Fig. 2B depicted that bufalin $(100 \mathrm{nM})$ 

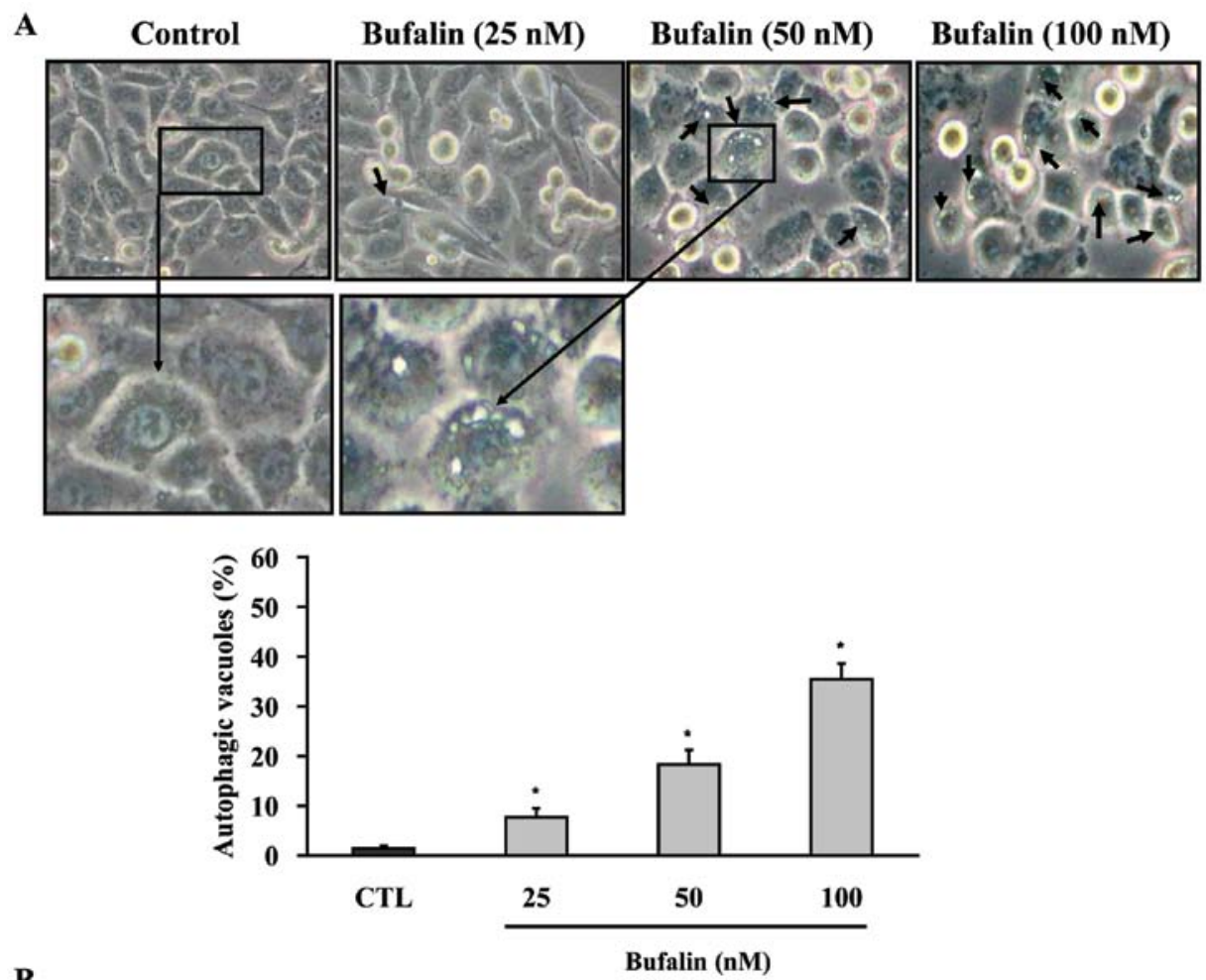

B

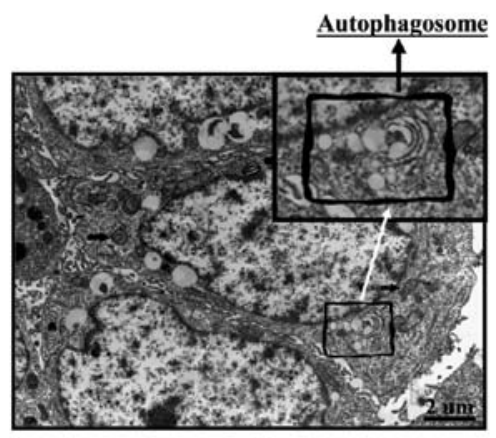

Control

Bufalin (100 nM)

Figure 4. Bufalin induced autophagic cell death in SK-HEP-1 cells. (A) SK-HEP-1 cells were treated with bufalin $(0,25,50$ and $100 \mathrm{nM})$ for $24 \mathrm{~h}$ and examined the formation of autophagic vacuoles by phase microscopy. (B) The formation of autophagosome vesicles in bufalin-treated SK-HEP-1 cells was analyzed by transmission electron microscopy.

caused a significant decrease in CDK1 activity for $0,6,12$ and 24-h treatment in SK-HEP-1 cells. Our data indicated that bufalin-treated SK-HEP-1 cells downregulated CDK1 activity and caused $\mathrm{G}_{2} / \mathrm{M}$ phase arrest.

Bufalin induces caspase-independent cell death in SK-HEP-1 cells. To examine whether bufalin induced apoptosis in SK-HEP-1 cells, cells were treated with bufalin $(0,50$ and $100 \mathrm{nM}$ ) for $24 \mathrm{~h}$, and analyzed DNA fragmentation by DNA gel electrophoresis. Fig. 3A showed that no DNA fragmentation was observed in SK-HEP-1 cells treated with bufalin for $24 \mathrm{~h}$. This result suggested that bufalin did not induce apoptosis in SK-HEP-1 cells. Similar result was obtained from TUNEL staining (Fig. 3B) when SK-HEP-1 cells were treated with bufalin $(0,50$ and $100 \mathrm{nM})$ or paclitaxel $(100 \mathrm{nM}$; an apoptotic agent) for $24 \mathrm{~h}$. Fig. 3B showed that the percentage of TUNEL positive cells in bufalin-treated SK-HEP-1 cells was less than
$5 \%$ compared with the paclitaxel-treated cells $(37.26 \pm 4.34 \%)$. To investigate whether bufalin-induced cell death is mediated through caspase-3 activation, SK-HEP-1 cells were treated with bufalin $(0,50$ and $100 \mathrm{nM})$ or paclitaxel $(100 \mathrm{nM}$; an apoptotic reagent) for $24 \mathrm{~h}$ and then analyzed the protein levels of cleaved caspase-3 and poly (ADP-ribose) polymerase (PARP), downstream target of caspase-3. As shown in Fig. 3C, the protein levels of cleaved caspase- 3 or cleaved PARP were not increased in bufalin-treated SK-HEP-1 cells. In addition, the caspase-3 activity showed no change in bufalin-treated SK-HEP-1 cells. Our results indicated that bufalin-induced cell death did not proceed through apoptosis in SK-HEP-1 cells.

Bufalin induces autophagic cell death in SK-HEP-1 cells. No apoptotic feature was detected in SK-HEP-1 cells. Next, we examine whether autophagic cell death is involved in bufalininduced cell death. SK-HEP-1 cells were treated with bufalin $(0$, 
A
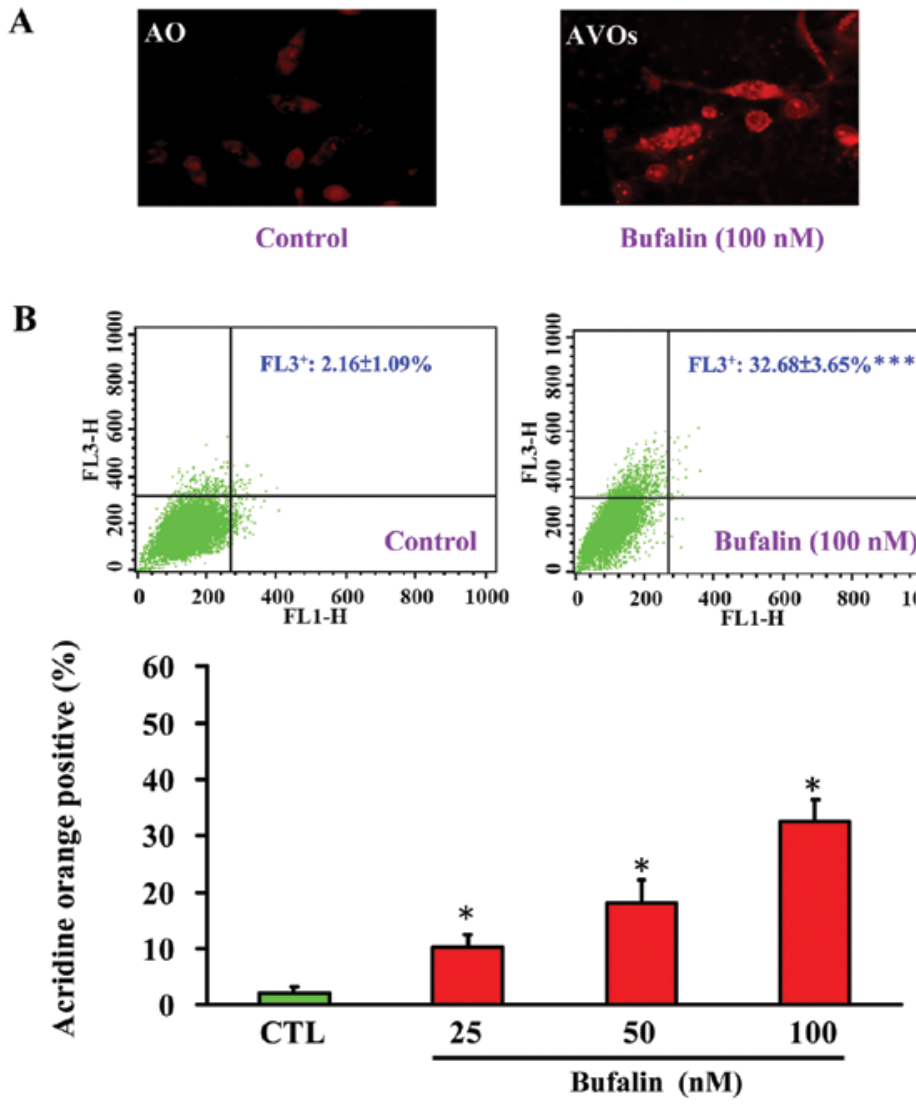
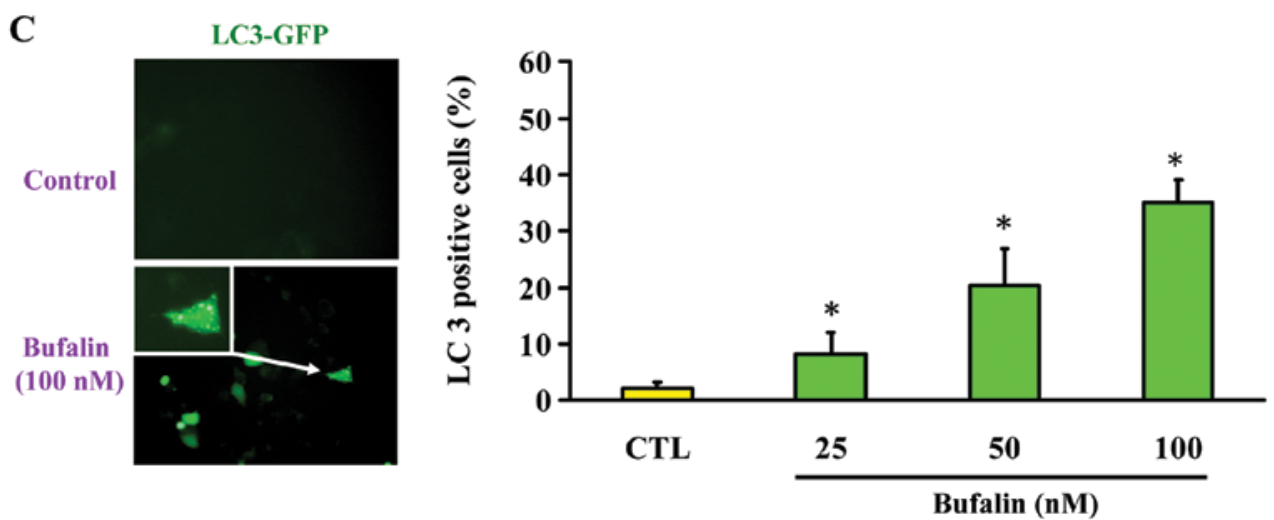

Figure 5. Autophagosomes and autolysosomes were present in bufalin-treated SK-HEP-1 cells. (A) Representative images of acridine orange (AO) staining of SK-HEP-1 cells in the absence or presence of $100 \mathrm{nM}$ bufalin. The cytosolic acidic vesicular organelles (AVOs) appeared in bufalin-treated SK-HEP-1 cells (B) AVOs were analyzed in bufalin-treated SK-HEP-1 cells. Percentage of acridine orange positive cells was determined by flow cytometry. (C) The punctate pattern of LC3-GFP in bufalin-treated SK-HEP-1 cells. Cells were treated with bufalin $(0,25,50$ and $100 \mathrm{nM})$ for $24 \mathrm{~h}$. Percentage of acridine orange positive cells was calculated. Data are presented as the mean \pm SEM of three independent experiments. ${ }^{*} \mathrm{P}<0.05$, significantly different compared with control treatment.

25,50 and $100 \mathrm{nM}$ ) for $24 \mathrm{~h}$ and the formation of autophagic vacuoles was examined by the phase microscopy. As shown in Fig. 4A, bufalin induced the formation of autophagic vacuoles in SK-HEP-1 cells in concentration-dependent manner. We further confirmed the formation of autophagosome vesicles in bufalintreated SK-HEP-1 cells using transmission electron microscopic (TEM) analysis (Fig. 4B). Double- or multi-membrane structure characteristics of autophagosomes and autolysosomes were present in bufalin-treated SK-HEP-1 cells. The cytosolic acidic vesicular organelles (AVOs) are one of the hallmarks of autophagic cell death. In Fig. 5A, acridine orange (AO) staining of bufalin-treated SK-HEP-1 cells clearly showed
AVOs within the cytoplasm compared to control by fluorescence microscopy. This observation was confirmed by FACS analysis, which showed a clear increase in red fluorescence (FL-3 positive) in concentration-dependent manner on bufalin-treated SK-HEP-1 cells (Fig. 5B). Furthermore, it has been shown that microtubule-associated protein 1 light-chain 3 (LC3) is an autophagic membrane marker for the detection of early autophagosome formation (50). We examined the LC3 distribution in bufalin-treated SK-HEP-1 cells by fluorescence microscopy and FACS analysis. As shown in Fig. 5C, bufalin treatment enhanced the punctate pattern of LC3-GFP in autophagic SK-HEP-1 cells. In addi- 
A
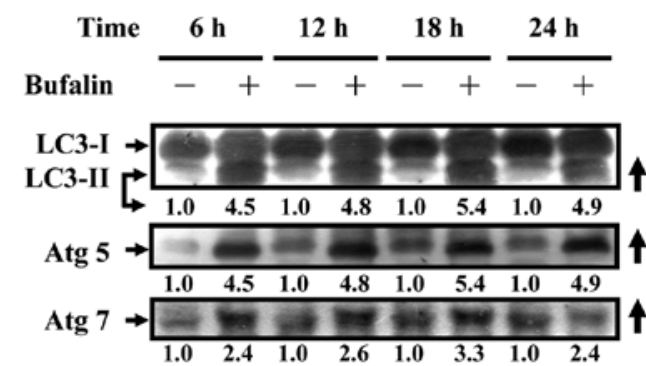

Atg $12 \rightarrow \square$ 个

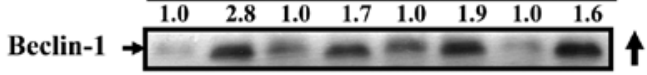

\begin{tabular}{llllllll}
1.0 & 3.9 & 1.0 & 3.5 & 1.0 & 4.2 & 1.0 & 4.4 \\
\hline & & & & & & &
\end{tabular}

\begin{tabular}{|llllllll} 
& & & & & & & \\
\hline 1.0 & 1.0 & 1.0 & 1.0 & 1.0 & 1.0 & 1.0 & 1.0
\end{tabular}

B

Bufalin $\frac{2 \mathrm{~h}}{-+} \frac{4 \mathrm{~h}}{-++} \frac{6 \mathrm{~h}}{-++} \frac{8 \mathrm{~h}}{-+}$

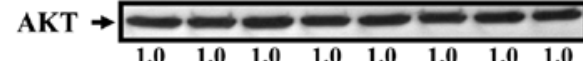

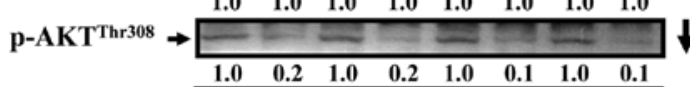

$\mathrm{p}-\mathrm{AKT}^{\mathrm{Ser} 473} \rightarrow$\begin{tabular}{lllllllll}
1.0 & 0.2 & 1.0 & 0.2 & 1.0 & 0.1 & 1.0 & 0.1 \\
\hline & & & & & & & & \\
\hline
\end{tabular}

\begin{tabular}{llllllll|}
1.0 & 0.2 & 1.0 & 0.2 & 1.0 & 0.1 & 1.0 & 0.1 \\
\hline
\end{tabular}

$\mathrm{mTOR} \rightarrow \mathrm{W}=$

\begin{tabular}{|lllllllll}
1.0 & 1.1 & 1.0 & 1.1 & 1.0 & 1.0 & 1.0 & 1.0 \\
\hline
\end{tabular}

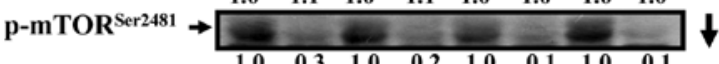

$\begin{array}{llllllll}1.0 & 0.3 & 1.0 & 0.2 & 1.0 & 0.1 & 1.0 & 0.1\end{array}$

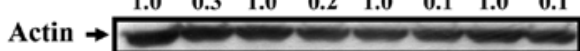

$\begin{array}{llllllll}1.0 & 1.0 & 1.0 & 1.0 & 1.0 & 1.0 & 1.0 & 1.0\end{array}$

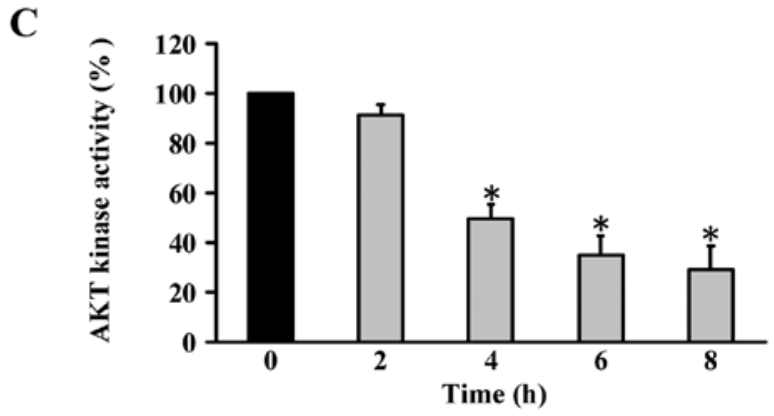

Figure 6. Expression levels of autophagy-associated proteins and the AKT/ mTOR signaling pathway in bufalin-treated SK-HEP-1 cells. (A) Cells were treated with $100 \mathrm{nM}$ of bufalin for the indicated time points. The protein levels of LC-3, Atg 5, Atg 7 and Atg 12, Beclin-1, and $\beta$-actin in bufalintreated SK-HEP-1 cells were examined by western blot analysis. (B) Cells were treated as described in (A). The protein levels of AKT, phospho-AKT (Thr308), phospho-AKT (Ser473), phospho-mTOR (Ser2481), mTOR, phospho-mTOR (Ser2481) and $\beta$-actin in bufalin-treated SK-HEP-1 cells were examined by western blot analysis. (C) AKT kinase activity was examined by an in vitro kinase activity assay. Data are presented as the mean \pm SEM of three independent experiments. ${ }^{*} \mathrm{P}<0.05$, significantly different compared with control treatment.

tion, an increase in the green fluorescence (FL-1 positive) cells by FACS analysis showed that bufalin-treated SK-HEP-1 cells underwent autophagic cell death in a concentrationdependent manner (Fig. 5C, right). Our results suggested that bufalin-induced cell death in SK-HEP-1 cells is dependent on the induction of autophagy.
A

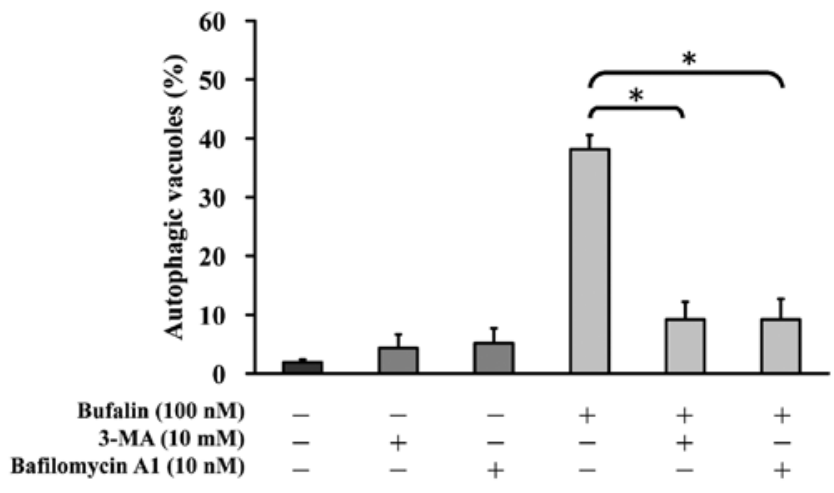

B

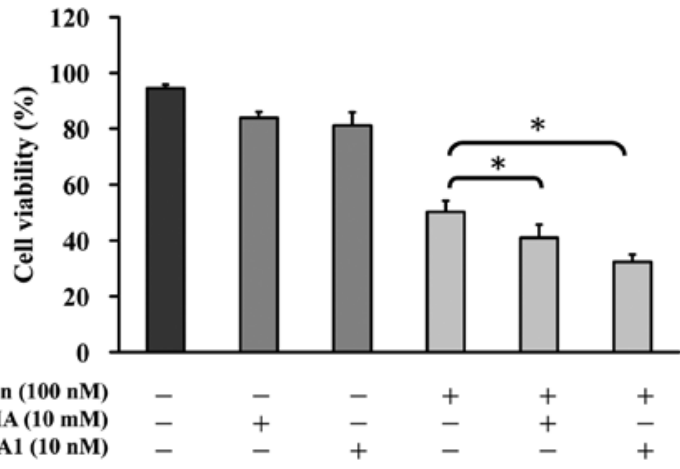

C

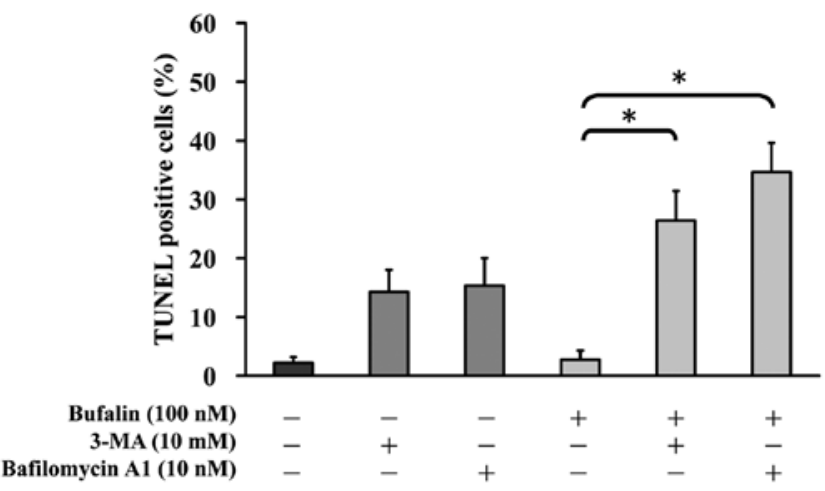

Figure 7. Effects of 3-methyladenine (3-MA) and bafilomycin A1 on autophagy and apoptosis in bufalin-treated SK-HEP-1 cells. SK-HEP-1 cells were pretreated with/without 3-MA $(10 \mathrm{mM})$ or bafilomycin $\mathrm{A} 1(10 \mathrm{nM})$, and then exposed to $100 \mathrm{nM}$ of bufalin for $24 \mathrm{~h}$. (A) Percentage of autophagic vacuoles was calculated. (B) Percentage of cell viability was calculated. (C) Percentage of TUNEL positive cells was calculated. Data are presented as the mean $\pm \mathrm{SEM}$ of three independent experiments. ${ }^{*} \mathrm{P}<0.05$, significantly different compared with control treatment.

Bufalin upregulates the autophagy-associated protein levels and blocks the AKT/mTOR signaling in SK-HEP-1 cells. Induced autophagic cell death is associated with the elevated protein levels of autophagic proteins LC-3, Atg complex (Atg 5, Atg 7 and Atg 12) and Beclin-1. We investigated the autophagyassociated protein levels in bufalin-treated SK-HEP-1 cells by western blot analysis. As shown in Fig. 6A, bufalin (100 nM) increased the protein levels of LC-3 II, Atg 5, Atg 7 and Atg 12 and Beclin-1 in SK-HEP-1 cells. It is also reported that the AKT activity contributed to autophagic cell death. 


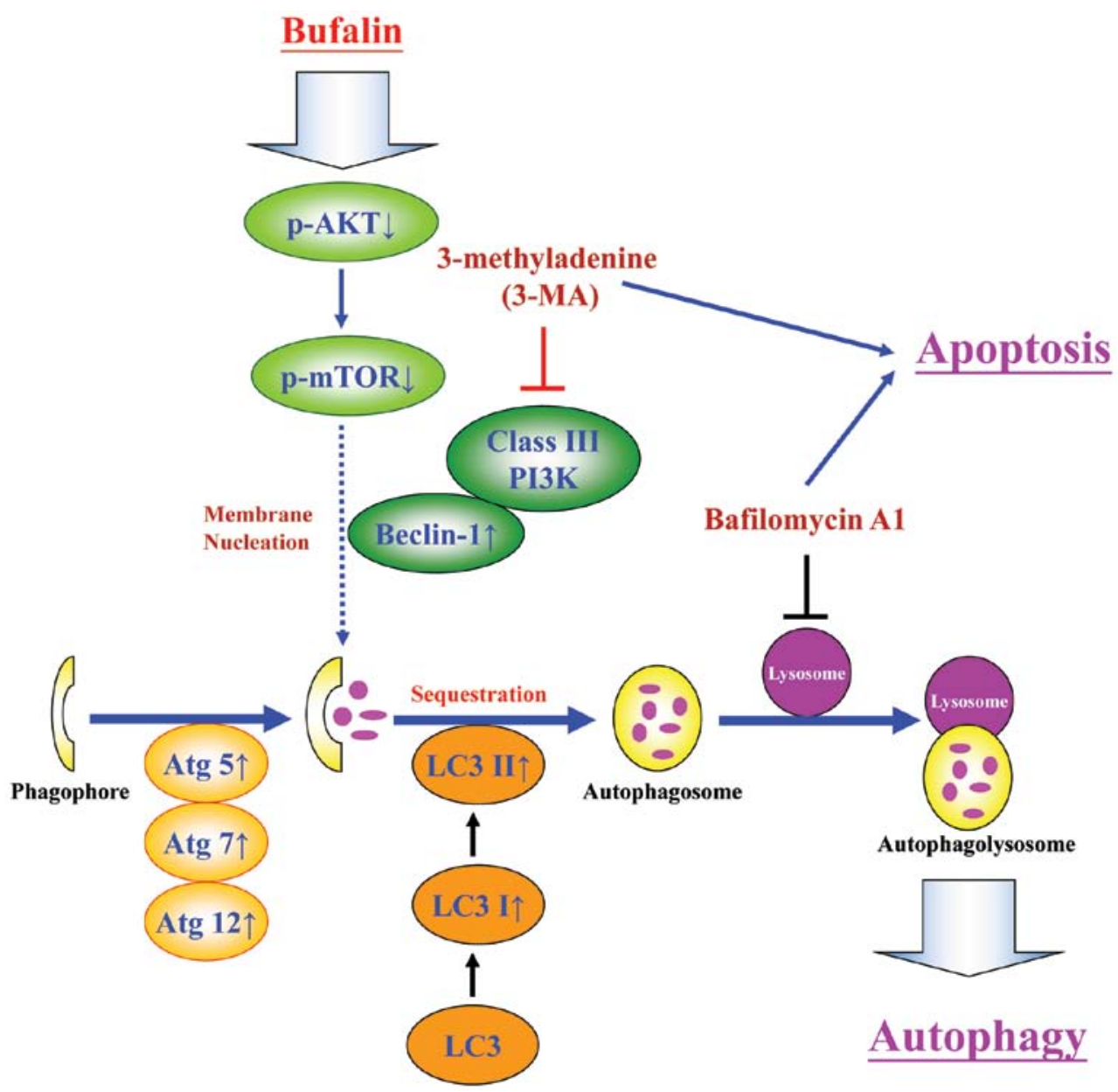

Figure 8. The working model of autophagic cell death in bufalin-treated SK-HEP-1 cells. For details, see text.

To examine whether bufalin-induced autophagic cell death is through the inhibition of AKT in SK-HEP-1 cells, cells were harvested after treatment with $100 \mathrm{nM}$ of bufalin for 2, 4, 6 and $8 \mathrm{~h}$, and then determined the protein levels by western blot analysis. Fig. 6B showed that bufalin (100 nM) significantly decreased the phospho-AKT (Thr308), phospho-AKT (Ser473), phospho-mTOR (Ser2481) protein levels in SK-HEP-1 cells. Bufalin decreased the AKT activity and this effect is timedependent (Fig. 6C). Our results implied that bufalin induced autophagic cell death in SK-HEP-1 cells through interfering with the AKT/mTOR signaling pathway.

3-Methyladenine and bafilomycin protect against autophagy and induce apoptosis in bufalin-treated SK-HEP-1 cells. 3-Methyladenine (3-MA), an inhibitor of class III phosphatidylinositol-3 kinase, is a reagent potently inhibiting autophagy-dependent protein degradation and suppressing the formation of autophagosomes (51), whereas bafilomycin A1, an inhibitor of the vacuolar proton pump of lysosomes and endosomes, appears to block the fusion of autophagosomes (52). In the present study, SK-HEP-1cells were pretreated with 3-MA $(10 \mathrm{mM})$ or bafilomycin A1 $(10 \mathrm{nM})$, and then exposed to $100 \mathrm{nM}$ of bufalin before harvested for measuring the levels of autophagic vacuoles and cell viability by MTT assay. Both 3-MA (10 mM) and bafilomycin A1 (10 nM) inhibit autophagic vacuoles (Fig. 7A) and reduce cell viability (Fig. 7B) in bufalin- treated SK-HEP-1 cells. Furthermore, we examined effects of 3-MA (10 mM) and bafilomycin A1 on apoptosis by TUNEL assay (Fig. 7C). The results showed both 3-MA (10 mM) and bafilomycin A1 (10 $\mathrm{nM})$ increased TUNEL positive apoptotic cells in bufalin-treated SK-HEP-1 cells. Taken together, inhibiting autophagic cell death by 3-MA or bafilomycin A1 facilitates bufalin-induced apoptosis in SK-HEP-1 cells.

\section{Discussion}

Traditional Chinese medicines (TCM) powerful for prevention or therapy of cancer are marked with their high anticancer activity and low toxicity in normal cells $(53,54)$. Bufalin has been used in clinical trials for cancer therapy in China (55). Han et al has demonstrated that bufalin has significant anti-human hepatocellular carcinoma activity in orthotopic transplantation nude mouse model in vivo and possesses no marked toxicity (56). Although bufalin upregulates Bax protein and induces tumor cell apoptosis in vivo, the signaling pathways underlying bufalin-induced cell death have not been elucidated. Arsenic trioxide, a TCM, has been reported to induce autophagic cell death without activation of caspasedependent apoptotic cell death (57). The current study focused on exploring molecular mechanisms of bufalin-induced cell death in human hepatocellular carcinoma SK-HEP-1 cells. Bufalin induced autophagic cell death through inhibiting the 
AKT/mTOR signaling pathway in SK-HEP-1 cells. Our results suggested that bufalin may be used as a novel therapeutic reagent for the medical treatment and/or prevention of human hepatocellular carcinoma.

In addition, we demonstrated that bufalin induced growth inhibitory effects through $\mathrm{G}_{2} / \mathrm{M}$ arrest (Fig. 1C) and autophagic cell death in SK-HEP-1 cells. Our results indicated that bufalin induced $\mathrm{G}_{2} / \mathrm{M}$ phase arrest (Fig. 1C). Cyclin A, cyclin B, CDK1, phospho-CDK1 (Thr161), Cdc25c, phospho-Cdc25c (Ser198) were decreased, while Chk1, Weel was increased by bufalin treatment in a time-dependent manner (Fig. 2A). It was reported in the $\mathrm{G}_{2} / \mathrm{M}$ phase progression, which is regulated with $\mathrm{CDK} 1$ and CDK2 kinases that are activated primarily in association with cyclins A and B. Furthermore, bufalin also inhibited the CDK1 activity (Fig. 2B). Previous studies have demonstrated that bufalin inhibited cell proliferation through induction of $\mathrm{G}_{0} / \mathrm{G}_{1}$ arrest of $\mathrm{T} 24$ human bladder cancer cells (46), human endometrial stromal cells, and ovarian cancer cells (58), but our findings indicated that bufalin induced different cell cycle phase arrest dependent on the cell types. The results are in agreement with previous studies indicated that bufalin inhibited cell proliferation through induction of $\mathrm{G}_{2} / \mathrm{M}$ arrest of endothelial cells (59), leukemia ML1 cells (60) and human osteosarcoma U-2OS and U-2OS methotrexate 300-resistant cells in vitro (61).

Autophagy plays two physiologic roles: one is protective role allowing cell survival and generating nutrients and energy; the other promotes cell death (62). When the cells undergo starvation, endoplasmic reticulum (ER) stress stimulation, ROS production and hypoxia, autophagy protects cells from the damage, which leads to cell survival (63). However, autophagy is observed to be induced by cytotoxic chemotherapeutic reagents such as paclitaxel (Taxol) (64), chloroquine, arsenic trioxide $(65,66)$, sorafenib $(67,68)$ and imiquimod $(69)$. Bufalin has been demonstrated to induce apoptosis and cell cycle arrest in leukemia (70), prostatic cancer (71), gastric cancer (72), ovarian cancer (58), osteosarcoma (61) and bladder cancer cells (59). In the present study, apoptotic characteristics such as DNA fragmentation, and cleavages of caspase-3 and PARP were not found in bufalin-treated SK-HEP-1 cells (Fig. 3C and D). Our data indicated that bufalin-induced cell death is caspase-independent apoptosis in SK-HEP-1 cells. Intriguingly, bufalin-induced autophagic cell death in SK-HEP-1 cells was demonstrated by several lines of evidence including autophagic vesicle formation (Fig. 4A), double-membrane vacuoles (Fig. 4B), acidic vesicular organelles (Fig. 5A), cleavage of microtubule-associated protein 1 light chain 3 (LC3) (Fig. 5C) and elevated protein levels of autophagic proteins, Atg complex (Atg 5, Atg 7 and Atg 12) and Beclin-1 (Fig. 6). When SK-HEP-1 cells were pre-treated with 3-MA or bafilomycin A1 followed by treating with bufalin, growth inhibitory effects and apoptosis were significantly enhanced compared with the bufalin alone treatment group by TUNEL assay (Fig. 7C). Our results suggested autophagy protects SK-HEP-1 cells from undergoing apoptosis in the early stage through antagonizing bufalin induced apoptosis. Our results did not rule out bufalin might be involved in apoptotic signaling pathways after longer exposure (more than $24 \mathrm{~h}$ ), but showed that SK-HEP-1 cells induced autophagic cell death after the $24 \mathrm{~h}$ treatment with bufalin. This is in agreement with the finding of Xie et al that human colorectal cancer HT-29 and Caco-2 cells treated with bufalin for $24 \mathrm{~h}$ and induced autophagy (34).

Previous studies demonstrated that autophagic cell death is triggered by multiple signaling pathways such as the adenosine monophosphate-activated protein kinase (AMPK) pathway $(73,74)$, the AKT/mammalian target of rapamycin (mTOR) pathway (75), the MAPK (ERK, p38 and JNK) pathway $(34,76)$, the BCL2 and its family members involved pathway (77), the death-associated protein kinase (DAPK) pathway and the death-associated related protein kinase 1 (DRP1) pathways (78). The AKT/mTOR pathway is involved in regulating cell survival and cell death. In the current study, bufalin inhibited protein levels of phospho-AKT (Thr308), phospho-AKT (Ser473), phospho-mTOR (Ser2481) and decreased the activity of AKT in SK-HEP-1 cells (Fig. 6B and C). Liu et al reported that AKT gene was overexpressed in hepatocellular carcinoma HCC and suggested that AKT activation participates in the pathogenesis and progression of HCC (79). Recently, our preliminary result demonstrated that human oral squamous cell carcinoma CAL 27 cells stably expressed constitutively active AKT (CA-AKT) increased AKT activity and attenuated bufalin-induced growth inhibition and cell death (data not shown). In the present study, the result showed that the AKT activity and AKT/mTOR pathway are associated with the induction of autophagic cell death in bufalin-treated SK-HEP-1 cells.

Overall, the molecular signaling pathways are summarized in Fig. 8. Our results demonstrated that the AKT/mTOR signaling pathway promotes autophagy in bufalin-treated SK-HEP-1 cells. These findings implied that bufalin may be used as a novel therapeutic reagent for the treatment of hepatocellular carcinoma.

\section{Acknowledgements}

This study was supported part by a research grant from the National Science Council of the Republic of China (NSC101-2313-B-039-008) awarded to J.-S. Yang and part by the grant from China Medical University (CMU100-TC-06) awarded to W.-W. Huang.

\section{References}

1. Tazi el M, Essadi I, M'Rabti H, Touyar A and Errihani PH: Systemic treatment and targeted therapy in patients with advanced hepatocellular carcinoma. N Am J Med Sci 3: 167-175, 2011.

2. Shariff MI, Cox IJ, Gomaa AI, Khan SA, Gedroyc W and Taylor-Robinson SD: Hepatocellular carcinoma: current trends in worldwide epidemiology, risk factors, diagnosis and therapeutics. Expert Rev Gastroenterol Hepatol 3: 353-367, 2009.

3. Simonetti RG, Camma C, Fiorello F, Politi F, D'Amico G and Pagliaro L: Hepatocellular carcinoma. A worldwide problem and the major risk factors. Dig Dis Sci 36: 962-972, 1991.

4. Takahashi H and Wands JR: Prognosis of hepatocellular carcinoma: known to be poor: yet difficult to predict. J Nucl Med 32: 235-236, 1991.

5. Kim JW, Lee JO, Han SW, et al: Clinical outcomes of sorafenib treatment in patients with metastatic hepatocellular carcinoma who had been previously treated with fluoropyrimidine plus platinum-based chemotherapy. Am J Clin Oncol 34: 125-129, 2011.

6. Luo HY, Yang JY, Liu ZM, Lin QY and Yan LN: Reversal of multidrug resistance gene MDR1 and MRP of drug-resistant human hepatocellular carcinoma cells SMMC-7721/ADM with antisense phosphorothioate oligonucleotides. Zhonghua Gan Zang Bing Za Zhi 12: 85-87, 2004 (In Chinese). 
7. Chang CS, Huang WT, Yang SS, Yeh HZ, Kao $\mathrm{CH}$ and Chen GH: Effect of P-glycoprotein and multidrug resistance associated protein gene expression on Tc-99m MIBI imaging in hepatocellular carcinoma. Nucl Med Biol 30: 111-117, 2003.

8. Shen DW, Lu YG, Chin KV, Pastan I and Gottesman MM: Human hepatocellular carcinoma cell lines exhibit multidrug resistance unrelated to MRD1 gene expression. J Cell Sci 98: 317-322, 1991.

9. Dai R, Chen R and Li H: Cross-talk between PI3K/Akt and MEK/ERK pathways mediates endoplasmic reticulum stress-induced cell cycle progression and cell death in human hepatocellular carcinoma cells. Int J Oncol 34: 1749-1757, 2009.

10. Chen GG, Chan UP, Bai LC, et al: ZBP-89 reduces the cell death threshold in hepatocellular carcinoma cells by increasing caspase- 6 and S phase cell cycle arrest. Cancer Lett 283: 52-58, 2009.

11. Wu SC and Zhang Y: Cyclin-dependent kinase 1(CDK1)-mediated phosphorylation of enhancer of zeste 2 (Ezh2) regulates its stability. J Biol Chem 286: 28511-28519, 2011

12. Hong KU, Kim HJ, Kim HS, et al: Cdk1-cyclin B1-mediated phosphorylation of tumor-associated microtubule-associated protein/cytoskeleton-associated protein 2 in mitosis. J Biol Chem 284: 16501-16512, 2009.

13. Yang JS, Hour MJ, Huang WW, Lin KL, Kuo SC and Chung JG: MJ-29 inhibits tubulin polymerization, induces mitotic arrest and triggers apoptosis via cyclin-dependent kinase 1-mediated Bcl-2 phosphorylation in human leukemia U937 cells. J Pharmacol Exp Ther 334: 477-488, 2010.

14. Rieder CL: Mitosis in vertebrates: the G2/M and M/A transitions and their associated checkpoints. Chromosome Res 19 291-306, 2011

15. Dustin P: Mitosis and differentiation; new thoughts on the biochemical regulation of growth in the vertebrates. Arch Anat Histol Embryol 34: 195-201, 1951.

16. Choi KS: Autophagy and cancer. Exp Mol Med 44: 109-120, 2012

17. Naumann P, Fortunato F, Zentgraf H, Buchler MW, Herr I and Werner J: Autophagy and cell death signaling following dietary sulforaphane act independently of each other and require ox idative stress in pancreatic cancer. Int J Oncol 39: 101-109, 2011.

18. Lee J, Giordano S and Zhang J: Autophagy, mitochondria and oxidative stress: cross-talk and redox signalling. Biochem J 441: 523-540, 2012.

19. McCormick J, Knight RA, Barry SP, et al: Autophagy in the stress-induced myocardium. Front Biosci (Elite Ed) 4 2131-2141, 2012

20. Li Y, Zhang Q, Tian R, et al: Lysosomal transmembrane protein LAPTM4B promotes autophagy and tolerance to metabolic stress in cancer cells. Cancer Res 71: 7481-7489, 2011.

21. Kung HJ: Targeting tyrosine kinases and autophagy in prostate cancer. Horm Cancer 2: 38-46, 2011.

22. Bursch W, Karwan A, Mayer M, et al: Cell death and autophagy: cytokines, drugs, and nutritional factors. Toxicology 254 $147-157,2008$

23. Martinez-Borra $\mathbf{J}$ and Lopez-Larrea C: Autophagy and selfdefense. Adv Exp Med Biol 738: 169-184, 2012.

24. Anders HJ and Schlondorff DO: Innate immune receptors and autophagy: implications for autoimmune kidney injury. Kidney Int 78: 29-37, 2010.

25. Munafo DB and Colombo MI: A novel assay to study autophagy: regulation of autophagosome vacuole size by amino acid deprivation. J Cell Sci 114: 3619-3629, 2001.

26. Yang ZJ, Chee CE, Huang S and Sinicrope FA: The role of autophagy in cancer: therapeutic implications. Mol Cancer Ther 10: 1533-1541, 2011.

27. Meschini S, Condello M, Lista P and Arancia G: Autophagy: molecular mechanisms and their implications for anticancer therapies. Curr Cancer Drug Targets 11: 357-379, 2011

28. Karantza-Wadsworth V and White E: Role of autophagy in breast cancer. Autophagy 3: 610-613, 2007.

29. Kelekar A: Autophagy. Ann NY Acad Sci 1066: 259-271, 2005.

30. Tanida I, Ueno T and Kominami E: LC3 conjugation system in mammalian autophagy. Int J Biochem Cell Biol 36: 2503-2518, 2004

31. Ropolo A, Bagnes CI, Molejon MI, et al: Chemotherapy and autophagy-mediated cell death in pancreatic cancer cells. Pancreatology 12: 1-7, 2012.

32. Guo XL, Li D, Hu F, et al: Targeting autophagy potentiates chemotherapy-induced apoptosis and proliferation inhibition in hepatocarcinoma cells. Cancer Lett 320: 171-179, 2012.
33. Yousefi S and Simon HU: Autophagy in cancer and chemotherapy. Results Probl Cell Differ 49: 183-190, 2009.

34. Xie CM, Chan WY, Yu S, Zhao J and Cheng CH: Bufalin induces autophagy-mediated cell death in human colon cancer cells through reactive oxygen species generation and JNK activation. Free Radic Biol Med 51: 1365-1375, 2011.

35. Lan YH, Chiang JH, Huang WW, et al: Activations of both extrinsic and intrinsic pathways in HCT 116 human colorectal cancer cells contribute to apoptosis through p53-mediated ATM/Fas signaling by Emilia sonchifolia extract, a folklore medicinal plant. Evid Based Complement Alternat Med 2012: 178178,2012

36. Lu HF, Lai KC, Hsu SC, et al: Curcumin induces apoptosis through FAS and FADD, in caspase-3-dependent and -independent pathways in the N18 mouse-rat hybrid retina ganglion cells. Oncol Rep 22: 97-104, 2009.

37. Lin HL, Yang JS, Yang JH, et al: The role of $\mathrm{Ca}^{2+}$ on the DADSinduced apoptosis in mouse-rat hybrid retina ganglion cells (N18). Neurochem Res 31: 383-393, 2006.

38. Chen HY, Lu HF, Yang JS, et al: The novel quinolone CHM-1 induces DNA damage and inhibits DNA repair gene expressions in a human osterogenic sarcoma cell line. Anticancer Res 30: 4187-4192, 2010

39. Chiu YJ, Hour MJ, Lu CC, et al: Novel quinazoline HMJ-30 induces U-2 OS human osteogenic sarcoma cell apoptosis through induction of oxidative stress and up-regulation of ATM/p53 signaling pathway. J Orthop Res 29: 1448-1456, 2011.

40. Huang SM, Yang JS, Tsai SC, et al: The novel synthesized 2-(3-(methylamino)phenyl)-6-(pyrrolidin-1-yl)quinolin-4-one (Smh-3) compound induces $\mathrm{G}_{2} / \mathrm{M}$ phase arrest and mitochondrial-dependent apoptotic cell death through inhibition of CDK1 and AKT activity in HL-60 human leukemia cells. Int J Oncol 38: 1357-1364, 2011.

41. Chung JG, Yang JS, Huang LJ, et al: Proteomic approach to studying the cytotoxicity of YC-1 on U937 leukemia cells and antileukemia activity in orthotopic model of leukemia mice. Proteomics 7: 3305-3317, 2007.

42. Li YC, Lin HJ, Yang JH, et al: Baicalein-induced apoptosis via endoplasmic reticulum stress through elevations of reactive oxygen species and mitochondria dependent pathway in mouse-rat hybrid retina ganglion cells (N18). Neurochem Res 34: 418-429, 2009

43. Yang JS, Chen GW, Hsia TC, et al: Diallyl disulfide induces apoptosis in human colon cancer cell line (COLO 205) through the induction of reactive oxygen species, endoplasmic reticulum stress, caspases casade and mitochondrial-dependent pathways. Food Chem Toxicol 47: 171-179, 2009.

44. Tseng MT, Lu X, Duan X, et al: Alteration of hepatic structure and oxidative stress induced by intravenous nanoceria. Toxicol Appl Pharmacol 260: 173-182, 2012.

45. Xiao D, Bommareddy A, Kim SH, Sehrawat A, Hahm ER and Singh SV: Benzyl isothiocyanate causes FoxO1-mediated autophagic death in human breast cancer cells. PLoS One 7: e32597, 2012

46. Huang WW, Yang JS, Pai SJ, et al: Bufalin induces $\mathrm{G}(0) / \mathrm{G}(1)$ phase arrest through inhibiting the levels of cyclin D, cyclin E, CDK2 and CDK4, and triggers apoptosis via mitochondrial signaling pathway in T24 human bladder cancer cells. Mutat Res 732: 26-33, 2012

47. Ip SW, Chu YL, Yu CS, et al: Bee venom induces apoptosis through intracellular $\mathrm{Ca}^{2+}$-modulated intrinsic death pathway in human bladder cancer cells. Int J Urol 19: 61-70, 2012.

48. Chiou SK, Hoa N and Hodges A: Sulindac sulfide induces autophagic death in gastric epithelial cells via survivin downregulation: a mechanism of NSAIDs-induced gastric injury. Biochem Pharmacol 81: 1317-1323, 2011.

49. Enomoto A, Murakami H, Asai N, et al: Akt/PKB regulates actin organization and cell motility via Girdin/APE. Dev Cell 9: 389-402, 2005.

50. Kabeya Y, Mizushima N, Ueno T, et al: LC3, a mammalian homologue of yeast Apg8p, is localized in autophagosome membranes after processing. EMBO J 19: 5720-5728, 2000.

51. Seglen PO and Gordon PB: 3-Methyladenine: specific inhibitor of autophagic/lysosomal protein degradation in isolated rat hepatocytes. Proc Natl Acad Sci USA 79: 1889-1892, 1982.

52. Yamamoto A, Tagawa Y, Yoshimori T, Moriyama Y, Masaki R and Tashiro Y: Bafilomycin A1 prevents maturation of autophagic vacuoles by inhibiting fusion between autophagosomes and lysosomes in rat hepatoma cell line, H-4-II-E cells. Cell Struct Funct 23: 33-42, 1998. 
53. Lee MJ, Chen HM, Tzang BS, et al: Ocimum gratissimum aqueous extract protects $\mathrm{H} 9 \mathrm{c} 2$ myocardiac cells from $\mathrm{H}(2)$ $\mathrm{O}(2)$-induced cell apoptosis through akt signalling. Evid Based Complement Alternat Med 2011: 578060, 2011.

54. Robbins D, Gu X, Shi R, et al: The chemopreventive effects of Protandim: modulation of p53 mitochondrial translocation and apoptosis during skin carcinogenesis. PLoS One 5: e11902, 2010.

55. Meng Z, Yang P, Shen Y, et al: Pilot study of huachansu in patients with hepatocellular carcinoma, nonsmall-cell lung cancer, or pancreatic cancer. Cancer 115: 5309-5318, 2009.

56. Han KQ, Huang G, Gu W, Su YH, Huang XQ and Ling CQ: Anti-tumor activities and apoptosis-regulated mechanisms of bufalin on the orthotopic transplantation tumor model of human hepatocellular carcinoma in nude mice. World J Gastroenterol 13: 3374-3379, 2007

57. Ondrouskova E, Soucek K, Horvath V and Smarda J: Alternative pathways of programmed cell death are activated in cells with defective caspase-dependent apoptosis. Leuk Res 32: 599-609, 2008.

58. Takai N, Ueda T, Nishida M, Nasu K and Narahara H: Bufalin induces growth inhibition, cell cycle arrest and apoptosis in human endometrial and ovarian cancer cells. Int J Mol Med 21: 637-643, 2008

59. Hong SH and Choi YH: Bufalin induces apoptosis through activation of both the intrinsic and extrinsic pathways in human bladder cancer cells. Oncol Rep 27: 114-120, 2012.

60. Jing Y, Watabe M, Hashimoto S, Nakajo S and Nakaya K: Cell cycle arrest and protein kinase modulating effect of bufalin on human leukemia ML1 cells. Anticancer Res 14: 1193-1198, 1994.

61. Yin JQ, Shen JN, Su WW, et al: Bufalin induces apoptosis in human osteosarcoma U-2OS and U-2OS methotrexate300resistant cell lines. Acta Pharmacol Sin 28: 712-720, 2007.

62. Codogno P: Autophagy in cell survival and death. J Soc Biol 199: 233-241, 2005 (In French).

63. Hoyer-Hansen M and Jaattela M: Autophagy: an emerging target for cancer therapy. Autophagy 4: 574-580, 2008.

64. Eum KH and Lee M: Crosstalk between autophagy and apoptosis in the regulation of paclitaxel-induced cell death in v-Ha-ras-transformed fibroblasts. Mol Cell Biochem 348 : 61-68, 2011.

65. Kanzawa T, Kondo Y, Ito H, Kondo S and Germano I: Induction of autophagic cell death in malignant glioma cells by arsenic trioxide. Cancer Res 63: 2103-2108, 2003.

66. Kanzawa T, Zhang L, Xiao L, Germano IM, Kondo Y and Kondo S: Arsenic trioxide induces autophagic cell death in malignant glioma cells by upregulation of mitochondrial cell death protein BNIP3. Oncogene 24: 980-991, 2005.
67. Bareford MD, Park MA, Yacoub A, et al: Sorafenib enhances pemetrexed cytotoxicity through an autophagy-dependent mechanism in cancer cells. Cancer Res 71: 4955-4967, 2011.

68. Ullen A, Farnebo M, Thyrell L, et al: Sorafenib induces apoptosis and autophagy in prostate cancer cells in vitro. Int J Oncol 37: 15-20, 2010

69. Huang SW, Liu KT, Chang CC, et al: Imiquimod simultaneously induces autophagy and apoptosis in human basal cell carcinoma cells. Br J Dermatol 163: 310-320, 2010.

70. Chen A, Yu J, Zhang L, et al: Microarray and biochemical analysis of bufalin-induced apoptosis of HL-60 Cells. Biotechnol Lett 31: 487-494, 2009.

71. Yu CH, Kan SF, Pu HF, Jea Chien E and Wang PS: Apoptotic signaling in bufalin- and cinobufagin-treated androgen-dependent and -independent human prostate cancer cells. Cancer Sci 99: 2467-2476, 2008.

72. Li D, Qu X, Hou K, et al: PI3K/Akt is involved in bufalininduced apoptosis in gastric cancer cells. Anticancer Drugs 20: 59-64, 2009.

73. Mihaylova MM and Shaw RJ: The AMPK signalling pathway coordinates cell growth, autophagy and metabolism. Nat Cell Biol 13: 1016-1023, 2011.

74. Hoyer-Hansen M and Jaattela M: AMP-activated protein kinase: a universal regulator of autophagy? Autophagy 3: 381-383, 2007

75. Shi WY, Xiao D, Wang L, et al: Therapeutic metformin/AMPK activation blocked lymphoma cell growth via inhibition of mTOR pathway and induction of autophagy. Cell Death Dis 3: e275, 2012

76. Corcelle E, Djerbi N, Mari M, et al: Control of the autophagy maturation step by the MAPK ERK and p38: lessons from environmental carcinogens. Autophagy 3: 57-59, 2007.

77. Levine B, Sinha S and Kroemer G: Bcl-2 family members: dual regulators of apoptosis and autophagy. Autophagy 4: 600-606, 2008.

78. Inbal B, Bialik S, Sabanay I, Shani G and Kimchi A: DAP kinase and DRP-1 mediate membrane blebbing and the formation of autophagic vesicles during programmed cell death. J Cell Biol 157: 455-468, 2002.

79. Liu L-X, Liu Z-H, Jiang H-C, et al: Overexpression of Akt-1 gene in human hepatocellular carcinoma. Chinese J Cancer Res 14: $161-164,2002$. 